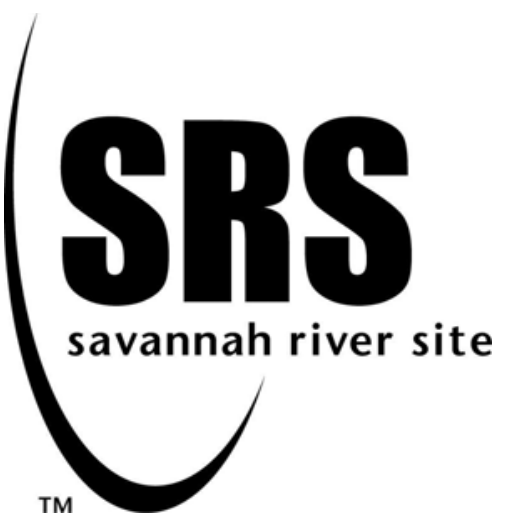

\title{
Calculation of Tritium Retention and Release from Components in Grout- Segment 6 Metallic Waste from Demolished Building 232-F
}

\author{
Elliot A. Clark
}

Publication Date: 9 February 2007

\section{Savannah River National Laboratory Washington Savannah River Company Savannah River Site Aiken, South Carolina}

This document was prepared in connection with work done under Contract No. DE-AC09-96SR18500 with the U.S. Department of Energy. By acceptance of this document, the publisher and/or recipient acknowledges the U.S. Government's right to retain a nonexclusive, royalty-free license in and to any copyright covering this document, along with the right to reproduce and authorize others to reproduce all or part of the copyrighted material.

WASHINGTON SAVANNAH RIVER COMPANY

The WSRC Team: Washington Savannah River Company LLC • Bechtel Savannah River, Inc. • BNG America Savannah River Corporation • BWXT Savannah River Company • CH2 Savannah River Company 


\section{DISCLAIMER}

This report was prepared as an account of work sponsored by an agency of the United States Government. Neither the United States Government nor any agency thereof, nor any of their employees, nor any of their contractors, subcontractors or their employees, makes any warranty, expressed or implied, or assumes any legal liability or responsibility for the accuracy, completeness, or any third party's use or the results of such use of any information, apparatus, product, or process disclosed, or represents that its use would not infringe privately owned rights. Reference herein to any specific commercial product, process, or service by trade name, trademark, manufacturer, or otherwise, does not necessarily constitute or imply its endorsement, recommendation, or favoring by the United States Government or any agency thereof or its contractors or subcontractors. The views and opinions of authors expressed herein do not necessarily state or reflect those of the United States Government or any agency thereof. 

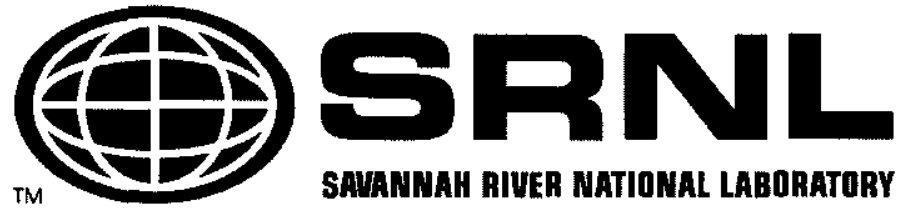

SAYANNAH RIUER NATIONAL LABORATORY

\section{MATERIALS SCIENCE AND TECHNOLOGY}

9 February 2007

Keywords: Tritium Radioactive Waste

Stainless Steel

Retention - Permanent

\section{Calculation of Tritium Retention and Release from Components in Grout- Segment 6 Metallic Waste from Demolished Building 232-F}

Elliot A. Clark

Materials Science and Technology

Savannah River National Laboratory, Aiken, South Carolina 29808

Washington Savannah River Company

Prepared for the U. S. Department of Energy under Contract DE-AC09-96SR18500 


\section{APPROVALS}

E.A. Clark, AUTHOR

Materials Compatibility and Joining Technology Group MATERIALS SCIENCE AND TECHNOLOGY

B.T Butcher, CUSTOMER

ENVIRONMETAL ANALYSIS AND PERFORMANCE

P.S. Korinko, TEC'HNICAL REVIEWER MATERIALS SCIENCE AND TECHNOLOGY

M.E. Dupont, ACTING MANAGER

Materials Compatibility and Welding Technology Group MATERIALS SCIENCE AND TECHNOLOGY

N.C. Iyer, DIRECTOR

MATERIALS SCIENCE AND TECHNOLOGY
Date:

Date:

Date:

Date:

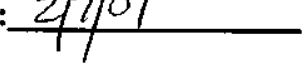

Date: 


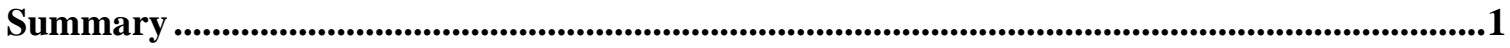

Calculation Overview ............................................................................................................................1

Background: Solution and Diffusion of Hydrogen Isotopes in Metals ......................................2

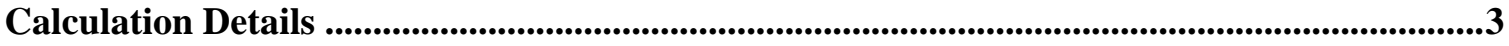

References ...............................................................................................................................................

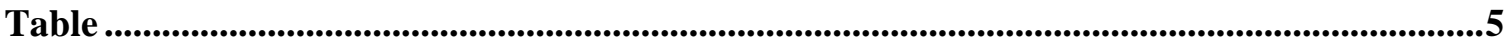

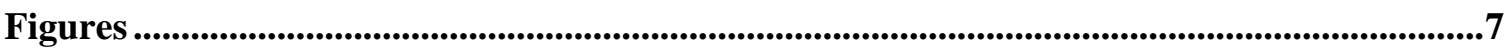

\section{TABLE}

I. Results of Each Step of Finite Difference Calculation .............................................................5

\section{FIGURES}

1. Calculation of Parameters for $1 / 2 "$ Schedule 40S Stainless Steel Pipe .......................................

2. Tritium remaining in CIG Segment 6 metallic waste as a function of year. ..............................8

3. Tritium outgas rate from CIG Segment 6 waste as function of year.........................................9 
PAGE INTENTIONALLY BLANK 


\title{
Calculation of Tritium Retention and Release from Components in Grout- Segment 6 Metallic Waste from Demolished Building 232-F
}

\author{
Elliot A. Clark \\ Materials Science and Technology \\ Savannah River National Laboratory
}

\begin{abstract}
Summary
The amount of tritium remaining within and the release rate out of stainless steel process waste from the 232-F Tritium Facility at SRS is calculated as a function of time using the historical exposure of pipe during operation of the facility (1955-1958) and its subsequent deactivation and lay-up. The solution and diffusion of tritium in the wall is the mechanism that governs both the tritium contamination of the pipe during operation and its gradual release after deactivation, including radioactive decay while in the metal. This analysis applies to Segment 6 of the so-called Components in Grout waste form. Results of these calculations will be used in the Groundwater Transport assessment, part of the analysis of the Components in Grout.
\end{abstract}

\section{Calculation Overview}

The $232-\mathrm{F}$ process waste is assumed to be $1 / 2$ " Schedule $40 \mathrm{~S}$ stainless steel pipe. It is assumed that 1 atmosphere $(14.7 \mathrm{psia})$ of tritium at ambient temperature $\left(25^{\circ} \mathrm{C}\right)$ filled the pipe for the entire three years the facility operated. The amount of tritium that permeated into the pipe wall during facility operation is calculated using a finite difference computer program (DIFF94)(Ref. 3). This program is commonly used at SRS to calculate hydrogen isotope concentration distribution and permeation rates in materials. When the $232-\mathrm{F}$ process was deactivated, the tritium gas was removed from the pipe. The remaining tritium in the pipe wall began permeating out into the interior of the pipe and then into the atmosphere. The same finite difference computer program is used to calculate the amount of tritium permeating out of the pipe as a function of time after the 232-F process was retired. Also, the program calculates the amount of tritium remaining in the pipe wall and includes the radioactive decay of tritium to $\mathrm{He}^{3}$. Knowing the density of stainless steel and the geometry of the pipe, the total internal surface area of the process pipe is calculated from the net weight of the 232-F process waste in Segment 6. The total amount of tritium leaving the process waste per unit time as a function of time (i.e., months or years since deactivation) is found by multiplying the offgas rate per unit area with the total pipe internal surface area. The total weight of pipe also allows the pipe metal volume to be calculated (the volume of stainless steel in the pipe wall). By multiplying the pipe metal volume by the tritium concentration remaining in the pipe, the total amount of tritium remaining in the metal is determined. This value is the amount of tritium remaining in Segment 6 at any given time. 


\section{Background: Solution and Diffusion of Hydrogen Isotopes in Metals}

Diatomic gases such as hydrogen and tritium dissolve in metals as single atoms according to Sievert's Law:

$$
\mathrm{S}=\mathrm{S}_{0} \cdot \sqrt{\mathrm{p}} \cdot e^{-\Delta \mathrm{H} / \mathrm{RT}}
$$

in which $\mathrm{p}$ is the gas partial pressure, $\Delta \mathrm{H}$ the heat of solution, $\mathrm{R}$ the gas constant, $\mathrm{T}$ the absolute temperature, and $\mathrm{S}_{0}$ the solubility constant. The solubility depends on the square root of the partial pressure because the diatomic hydrogen molecules dissociate at the surface and dissolve as single atoms [1].

Once dissolved, hydrogen atoms diffuse within solid materials according to Fick's Laws [2]:

$$
\mathrm{J}=-\mathrm{D} \cdot \frac{\partial \mathrm{c}}{\partial \mathrm{x}} 2
$$

and

$$
\frac{\partial c}{\partial t}=\mathrm{D} \cdot \frac{\partial^{2} c}{\partial x^{2}}
$$

in which $\mathrm{J}$ is the flux (amount of matter diffusing per unit area per unit time (units are $\mathrm{cc}_{2}$ @ STP/ $\mathrm{cm}^{2}$-s, discussed further below, cc is cubic centimeters), D the diffusion coefficient (in $\mathrm{cm}^{2} / \mathrm{s}$ ), and $\mathrm{c}(\mathrm{x}, \mathrm{t})$ is the concentration (or more generally, the chemical potential) of hydrogen in the metal as a function of position $\mathrm{x}$ and time $\mathrm{t}$ (units are $\mathrm{cc}_{2} @ \mathrm{STP} / \mathrm{cc}$ metal). Eq. 2 states that a net flux of atoms is established when a concentration gradient exists. Eq. 3 is the partial differential equation that describes the time and spatial variation of concentration of a diffusing species in a concentration gradient. The diffusion coefficient $\mathrm{D}$ describes the diffusion rate for a given solute in a given solvent, and normally varies exponentially with temperature:

$$
\mathrm{D}=\mathrm{D}_{0} \cdot e^{-\mathrm{Q} / \mathrm{RT}} .
$$

4

$\mathrm{D}$ is invariant with pressure at the pressure and temperature considered here. Eq. 3 can be solved, for given initial and boundary conditions, to find the concentration as a function of position and time in the wall, $\mathrm{c}(\mathrm{x}, \mathrm{t})$, and from this condition the flux (amount per unit area per unit time) permeating out of the pipe is calculated using Eq. 3 evaluated at the inner surface of the pipe. Analytical solutions to Eq. 3 exist for specific cases, and numerical solutions can be found for any case using finite difference methods. The computer program DIFF94 employs a finite difference method for this calculation.

"cc $\mathrm{H}_{2} @$ STP" is a measure of quantity of hydrogen, i.e., the volume in cubic centimeters the quantity of hydrogen would occupy if it were a gas at Standard Temperature and Pressure (STP), which is $273 \mathrm{Kelvin}\left(0^{\circ} \mathrm{C}\right.$.) and 1 atmosphere pressure). This unit is used extensively at the Savannah River Site Tritium Facilities. cc $\mathrm{H}_{2} @$ STP is related to moles by: 


$$
n=\frac{(1 a t m) *\left[c c H_{2} @ S T P\right]}{R * 273}
$$

in which $\mathrm{n}$ is number of gram moles. The universal gas constant $\mathrm{R}$ is $82.05 \mathrm{cc}-\mathrm{atm} / \mathrm{Kelvin}$. Note that hydrogen isotopes exist as atoms when dissolved in metals, so that the number of atoms per unit volume dissolved in the metal is twice the number of diatomic molecules in Eq. 5 and used in the unit "cc $\mathrm{H}_{2} @$ @TP”.

\section{Calculation Details}

As indicated above, the $232-\mathrm{F}$ process waste is assumed to be $1 / 2$ " Schedule $40 \mathrm{~S}$ stainless steel pipe. This pipe size was typical both of 232-F tritium process and the later 232-H and $\mathrm{H}$ Area Old Manufacturing (HAOM) tritium processes. The pipe was assumed to be filled with 1 atmosphere absolute of $100 \%$ tritium gas for the entire three-year (36 month) life of the facility (from 1955 to 1958), and then the partial pressure of tritium was assumed to be zero from 1958 onward. The temperature both during operation and afterward was assumed to be $25^{\circ} \mathrm{C}$. DIFF94, a finite difference computer program [3], was used to calculate the amount and distribution of tritium in the pipe wall (using Eqs. 1-4 above) established during tritium exposure and after exposure (i.e., during deactivation and waste disposal). The program also calculated the flux of tritium coming out of the pipe from the inside wall. The amount of tritium exiting the outside wall, based on the tritium concentration profile, was calculated to be zero. For simplicity and fewer calculation estimates, the calculation was performed for a 0.109 " thick one dimensional slab rather than a cylindrical geometry. The final calculation employed 50 time steps having lengths from 0.1 to 120 months; another run using 25 steps resulted in identical results for the exit flux (this means that the time steps were short enough to ensure the program had converged to the true solution). The 50 time step calculation is reported here because it extends out to longer time. The first time step was the initial three year (36 month) exposure to tritium at 1 atm and $25^{\circ} \mathrm{C}$. Subsequent time steps allow the tritium flux and the amount remaining in the pipe wall to be calculated and plotted as a function of time. The calculation was performed out to the year 2170 , over 16 half lives. The results of this calculation are the flux of tritium exiting the pipe in units of $\mathrm{cc}_{2} @$ STP per $\mathrm{cm}^{2}$ per second and the average amount of tritium residing in the pipe in units of $\mathrm{cc}_{2} @$ STP per cc of metal. Table I presents results of this calculation. The tritium flux out of pipe at the end of step 1 is not applicable because the tritium is still permeating into the pipe from the $1 \mathrm{~atm}$. tritium gas source within the pipe.

To convert the calculated tritium flux out of the pipe and remaining concentration in the pipe to an annual rate of total curies tritium exiting the waste in Segment 6 and remaining total curies tritium in Segment 6, the volume of contaminated pipe is calculated assuming the net weight of the 232-F process waste is entirely comprised of $1 / 2$ " Schedule 40S stainless steel pipe. The net weight of the waste is calculated from the SRS Waste Information Tracking System (WITS), which has the weight of all items in Segment 6; the total weight for segment 6 is the sum of the weights of each item. Schedule 40S has a wall thickness of 0.109", an inside diameter of 0.622 ", and an outside diameter of 0.840 ". The calculations of the pipe volume and surface area are presented in Figure 1. From the weight of pipe, the metal volume of pipe is calculated using the density of stainless steel. The assumed geometry of the pipe also allows the total internal surface area to be calculated. Table I contains the calculated curies tritium remaining in the waste at the end of each step and the 
evolution rate in curies/year during each step. Figures 2 and 3 are graphs of the calculated tritium retention and release rate (respectively) from CIG Segment 6.

\section{$\underline{\text { References }}$}

1. J.D. Fast. "Interaction of Metals and Gases: Vol. 1 Thermodynamics and Phase Relations", Chapt. 7, Academic Press, NY (1965).

2. P.G. Shewmon, "Diffusion in Solids", Chapter 1, J. Williams Book Company, Jenks, Oklahoma USA (1983).

3. K.E. Kain, "Finite-Difference Program for Hydrogen Diffusion", Report DP-1738, E.I. du Pont de Nemours \& Co., Savannah River Laboratory, DOE Savannah River Site, Aiken, SC, March (1987). 
Table I. Results of Each Step of Finite Difference Calculation

\begin{tabular}{|c|c|c|c|c|c|c|c|c|}
\hline Step & $\begin{array}{l}\frac{\text { Step }}{\text { Length }} \\
\text { (month) } \\
\end{array}$ & $\begin{array}{l}\frac{\text { Elapsed Time }}{\text { at End of Step }} \\
\text { (months) }\end{array}$ & $\begin{array}{l}\frac{\text { Elapsed Time }}{\text { at End of Step }} \\
\text { (years) }\end{array}$ & $\frac{\frac{\text { Calendar }}{\text { Year at }}}{\frac{\text { End of }}{\text { Step }}}$ & $\begin{array}{c}\frac{\text { Average T2 }}{\text { concentraion }} \\
\frac{\text { in pipe wall }}{\text { (cc } \mathrm{H}_{2} @ \text { STP/ }} \\
\text { cc metal) }\end{array}$ & $\begin{array}{c}\frac{\text { Tritium }}{\text { Flux out of }} \\
\frac{\text { plipe (cc H }_{2}}{\text { pipe }} \\
\frac{\text { @ STP }}{\left./ \mathrm{s} / \mathrm{cm}^{\wedge} 2\right)} \\
\end{array}$ & $\frac{\stackrel{\text { Ci }}{\text { Remaining }}}{\frac{\text { in metal }}{\text { waste }(\mathrm{Ci})}}$ & $\begin{array}{c}\frac{\text { Yearly tritium }}{\frac{\text { evolution out }}{\text { of pipe surface }}} \\
\frac{(\mathrm{Ci} / \mathrm{y})}{}\end{array}$ \\
\hline 1 & 36 & 36 & 3.0 & 1958.0 & $2.68 \mathrm{E}-03$ & $\# \mathrm{~N} / \mathrm{A}$ & 62924.36 & $\# \mathrm{~N} / \mathrm{A}$ \\
\hline 2 & 0.1 & 36.1 & 3.0 & 1958.0 & $1.08 \mathrm{E}-03$ & $1.11 \mathrm{E}-12$ & 25414.14 & 2537.99 \\
\hline 3 & 0.5 & 36.6 & 3.1 & 1958.1 & $1.07 \mathrm{E}-03$ & $1.10 \mathrm{E}-12$ & 25231.32 & 2505.05 \\
\hline 4 & 1 & 37.6 & 3.1 & 1958.1 & $1.06 \mathrm{E}-03$ & $1.07 \mathrm{E}-12$ & 24871.73 & 2440.71 \\
\hline 5 & 3 & 40.6 & 3.4 & 1958.4 & $1.01 \mathrm{E}-03$ & $9.91 \mathrm{E}-13$ & 23839.28 & 2259.29 \\
\hline 6 & 6 & 46.6 & 3.9 & 1958.9 & $9.34 \mathrm{E}-04$ & $8.52 \mathrm{E}-13$ & 21963.89 & 1943.02 \\
\hline 7 & 6 & 52.6 & 4.4 & 1959.4 & 8.64E-04 & $7.36 \mathrm{E}-13$ & 20307.95 & 1679.11 \\
\hline 8 & 6 & 58.6 & 4.9 & 1959.9 & $8.01 \mathrm{E}-04$ & $6.39 \mathrm{E}-13$ & 18837.98 & 1457.89 \\
\hline 9 & 6 & 64.6 & 5.4 & 1960.4 & $7.45 \mathrm{E}-04$ & $5.58 \mathrm{E}-13$ & 17526.41 & 1271.62 \\
\hline 10 & 6 & 70.6 & 5.9 & 1960.9 & $6.95 \mathrm{E}-04$ & $4.89 \mathrm{E}-13$ & 16350.50 & 1114.09 \\
\hline 11 & 12 & 82.6 & 6.9 & 1961.9 & $6.10 \mathrm{E}-04$ & $3.80 \mathrm{E}-13$ & 14333.18 & 866.05 \\
\hline 12 & 12 & 94.6 & 7.9 & 1962.9 & $5.39 \mathrm{E}-04$ & $3.00 \mathrm{E}-13$ & 12669.33 & 683.92 \\
\hline 13 & 12 & 106.6 & 8.9 & 1963.9 & $4.80 \mathrm{E}-04$ & $2.40 \mathrm{E}-13$ & 11276.48 & 547.91 \\
\hline 14 & 12 & 118.6 & 9.9 & 1964.9 & $4.29 \mathrm{E}-04$ & $1.95 \mathrm{E}-13$ & 10095.32 & 444.67 \\
\hline 15 & 12 & 130.6 & 10.9 & 1965.9 & $3.86 \mathrm{E}-04$ & $1.60 \mathrm{E}-13$ & 9082.39 & 365.10 \\
\hline 16 & 18 & 148.6 & 12.4 & 1967.4 & $3.32 \mathrm{E}-04$ & $1.21 \mathrm{E}-13$ & 7809.77 & 276.86 \\
\hline 17 & 18 & 166.6 & 13.9 & 1968.9 & $2.88 \mathrm{E}-04$ & $9.39 \mathrm{E}-14$ & 6765.98 & 214.11 \\
\hline 18 & 18 & 184.6 & 15.4 & 1970.4 & $2.51 \mathrm{E}-04$ & $7.38 \mathrm{E}-14$ & 5897.29 & 168.34 \\
\hline 19 & 18 & 202.6 & 16.9 & 1971.9 & $2.20 \mathrm{E}-04$ & $5.89 \mathrm{E}-14$ & 5165.73 & 134.21 \\
\hline 20 & 24 & 226.6 & 18.9 & 1973.9 & $1.85 \mathrm{E}-04$ & $4.43 \mathrm{E}-14$ & 4356.96 & 101.03 \\
\hline 21 & 24 & 250.6 & 20.9 & 1975.9 & $1.57 \mathrm{E}-04$ & $3.39 \mathrm{E}-14$ & 3696.56 & 77.36 \\
\hline 22 & 24 & 274.6 & 22.9 & 1977.9 & $1.34 \mathrm{E}-04$ & $2.63 \mathrm{E}-14$ & 3151.41 & 60.09 \\
\hline 23 & 24 & 298.6 & 24.9 & 1979.9 & $1.15 \mathrm{E}-04$ & $2.07 \mathrm{E}-14$ & 2697.43 & 47.22 \\
\hline 24 & 24 & 322.6 & 26.9 & 1981.9 & $9.85 \mathrm{E}-05$ & $1.64 \mathrm{E}-14$ & 2316.67 & 37.49 \\
\hline 25 & 24 & 346.6 & 28.9 & 1983.9 & 8.49E-05 & $1.32 \mathrm{E}-14$ & 1995.40 & 30.01 \\
\hline 26 & 24 & 370.6 & 30.9 & 1985.9 & 7.33E-05 & $1.06 \mathrm{E}-14$ & 1722.98 & 24.21 \\
\hline 27 & 24 & 394.6 & 32.9 & 1987.9 & $6.34 \mathrm{E}-05$ & $8.62 \mathrm{E}-15$ & 1491.00 & 19.66 \\
\hline 28 & 48 & 442.6 & 36.9 & 1991.9 & $4.77 \mathrm{E}-05$ & $5.78 \mathrm{E}-15$ & 1122.73 & 13.17 \\
\hline 29 & 48 & 490.6 & 40.9 & 1995.9 & $3.62 \mathrm{E}-05$ & $3.94 \mathrm{E}-15$ & 850.59 & 8.99 \\
\hline 30 & 48 & 538.6 & 44.9 & 1999.9 & $2.75 \mathrm{E}-05$ & $2.73 \mathrm{E}-15$ & 647.61 & 6.23 \\
\hline 31 & 48 & 586.6 & 48.9 & 2003.9 & $2.11 \mathrm{E}-05$ & $1.91 \mathrm{E}-15$ & 495.10 & 4.37 \\
\hline 32 & 48 & 634.6 & 52.9 & 2007.9 & $1.62 \mathrm{E}-05$ & $1.36 \mathrm{E}-15$ & 379.80 & 3.09 \\
\hline 33 & 48 & 682.6 & 56.9 & 2011.9 & $1.24 \mathrm{E}-05$ & $9.69 \mathrm{E}-16$ & 292.21 & 2.21 \\
\hline 34 & 48 & 730.6 & 60.9 & 2015.9 & $9.59 \mathrm{E}-06$ & $6.98 \mathrm{E}-16$ & 225.39 & 1.59 \\
\hline 35 & 48 & 778.6 & 64.9 & 2019.9 & 7.41E-06 & $5.06 \mathrm{E}-16$ & 174.23 & 1.15 \\
\hline 36 & 120 & 898.6 & 74.9 & 2029.9 & $3.92 \mathrm{E}-06$ & $2.32 \mathrm{E}-16$ & 92.26 & 0.53 \\
\hline 37 & 120 & 1018.6 & 84.9 & 2039.9 & $2.10 \mathrm{E}-06$ & $1.09 \mathrm{E}-16$ & 49.29 & 0.25 \\
\hline 38 & 120 & 1138.6 & 94.9 & 2049.9 & $1.13 \mathrm{E}-06$ & $5.26 \mathrm{E}-17$ & 26.52 & 0.12 \\
\hline 39 & 120 & 1258.6 & 104.9 & 2059.9 & $6.10 \mathrm{E}-07$ & $2.57 \mathrm{E}-17$ & 14.34 & 0.06 \\
\hline 40 & 120 & 1378.6 & 114.9 & 2069.9 & $3.31 \mathrm{E}-07$ & $1.28 \mathrm{E}-17$ & 7.78 & 0.03 \\
\hline 41 & 120 & 1498.6 & 124.9 & 2079.9 & $1.80 \mathrm{E}-07$ & $6.41 \mathrm{E}-18$ & 4.24 & 0.01 \\
\hline 42 & 120 & 1618.6 & 134.9 & 2089.9 & $9.83 \mathrm{E}-08$ & $3.25 \mathrm{E}-18$ & 2.31 & 7.41E-03 \\
\hline 43 & 120 & 1738.6 & 144.9 & 2099.9 & $5.37 \mathrm{E}-08$ & $1.66 \mathrm{E}-18$ & 1.26 & $3.79 \mathrm{E}-03$ \\
\hline 44 & 120 & 1858.6 & 154.9 & 2109.9 & $2.94 \mathrm{E}-08$ & $8.56 \mathrm{E}-19$ & $6.92 \mathrm{E}-01$ & $1.95 \mathrm{E}-03$ \\
\hline
\end{tabular}




\begin{tabular}{|c|c|c|c|c|c|c|c|c|}
\hline Step & $\begin{array}{l}\frac{\text { Step }}{\text { Length }} \\
\text { (month) }\end{array}$ & $\begin{array}{l}\frac{\text { Elapsed Time }}{\text { at End of Step }} \\
\text { (months) }\end{array}$ & $\begin{array}{l}\frac{\text { Elapsed Time }}{\text { at End of Step }} \\
\text { (years) }\end{array}$ & $\frac{\frac{\text { Calendar }}{\text { Year at }}}{\frac{\text { End of }}{\text { Step }}}$ & $\begin{array}{l}\frac{\text { Average T2 }}{\text { concentraion }} \\
\frac{\text { in pipe wall }}{\text { (cc H }} \text { @ STP } / \\
\text { cc metal) }\end{array}$ & $\begin{array}{c}\frac{\text { Tritium }}{\text { Flux out of }} \\
\frac{\text { pipe (cc } \mathrm{H}_{2}}{@} \\
\frac{@ \mathrm{STP}}{\mid \mathrm{s} / \mathrm{cm}^{\wedge} 2} \\
\end{array}$ & $\frac{\underline{\text { Ci }}}{\frac{\text { Remaining }}{\text { in metal }}}$ & $\begin{array}{c}\frac{\text { Yearly tritium }}{\text { evolution out }} \\
\frac{\begin{array}{c}\text { of pipe surface } \\
\text { (Ci/y) }\end{array}}{}\end{array}$ \\
\hline 45 & 120 & 1978.6 & 164.9 & 2119.9 & $1.61 \mathrm{E}-08$ & $4.43 \mathrm{E}-19$ & $3.79 \mathrm{E}-01$ & $1.01 \mathrm{E}-03$ \\
\hline 46 & 120 & 2098.6 & 174.9 & 2129.9 & 8.84E-09 & $2.31 \mathrm{E}-19$ & $2.08 \mathrm{E}-01$ & $5.27 \mathrm{E}-04$ \\
\hline 47 & 120 & 2218.6 & 184.9 & 2139.9 & $4.85 \mathrm{E}-09$ & $1.21 \mathrm{E}-19$ & $1.14 \mathrm{E}-01$ & $2.76 \mathrm{E}-04$ \\
\hline 48 & 120 & 2338.6 & 194.9 & 2149.9 & $2.66 \mathrm{E}-09$ & $6.36 \mathrm{E}-20$ & $6.26 \mathrm{E}-02$ & $1.45 \mathrm{E}-04$ \\
\hline 49 & 120 & 2458.6 & 204.9 & 2159.9 & $1.46 \mathrm{E}-09$ & $3.36 \mathrm{E}-20$ & 3.44E-02 & $7.66 \mathrm{E}-05$ \\
\hline 50 & 120 & 2578.6 & 214.9 & 2169.9 & $8.04 \mathrm{E}-10$ & $1.78 \mathrm{E}-20$ & $1.89 \mathrm{E}-02$ & $4.06 \mathrm{E}-05$ \\
\hline
\end{tabular}


1/2" Schd 40 pipe:

Wall thickness

\begin{tabular}{c|c|c}
$\mathbf{0 . 1 0 9}$ & $* 2.54=$ & $\underline{0.277}$ \\
\hline In & $\mathrm{cm} / \mathrm{in}$ & $\mathrm{Cm}$
\end{tabular}

\section{Ouside diameter}

0.840

In

\begin{tabular}{l|c}
$2.54=$ & $\underline{2.134}$ \\
\hline $\mathrm{cm} / \mathrm{in}$ & $\mathrm{Cm}$
\end{tabular}

Inside diameter

0.622

\begin{tabular}{l|c}
$2.54=$ & $\underline{1.580}$ \\
\hline $\mathrm{cm} / \mathrm{in}$ & $\mathrm{Cm}$
\end{tabular}

Wall cross-sect. area

$=\pi^{*}\left((\text { Outside diameter } / 2)^{\wedge} 2-(\text { Inside diameter } / 2)^{\wedge} 2\right)=$

$\underline{1.615}$

$\mathrm{cm}^{\wedge} 2$

Inside circumference

$=\pi *$ Inside diameter $=$

$\underline{4.963}$

$\mathrm{cm}$

Weight of Pipe

from WITS, CIG Segment

6

Stainless steel density

Pipe metal volume

Pipe length

Pipe inner wall area
$=$ Inside circumference $*$ length $=$

$7.8 \mathrm{~g} / \mathrm{cc}$

$$
=\text { Weight } / \text { density }=
$$

$=$ Pipe metal volume $/$ Wall cross-sect. area $=$

$5,623,708$

$\mathrm{cm}$

$\underline{27,912,372}$

$\mathrm{cm}^{\wedge} 2$
Curies percc H2@STP

Seconds per year
2.589

$31,557,600$

\begin{tabular}{l|c|l|c}
$\begin{array}{l}\text { Total tritium remaining in } \\
\text { metal }\end{array}$ & = Average $\mathrm{T}_{2}$ concentration in pipe wall & $* 2.589$ & $\begin{array}{l}* \text { Pipe metal } \\
\text { volume }\end{array}$ \\
\hline$(\mathrm{Ci})$ & $\mathrm{cc} \mathrm{H} 2 @ \mathrm{STP} / \mathrm{cc}$ metal & $\begin{array}{l}\mathrm{Ci} / \mathrm{cc} \\
\mathrm{H}_{2} @ \mathrm{STP}\end{array}$ & $\mathrm{Cc}$
\end{tabular}

\begin{tabular}{l|l|l|c}
$\begin{array}{l}\text { Yearly tritium evolution } \\
\text { out pipe surface }\end{array}$ & =Tritium flux out of pipe *2.589 & $\begin{array}{l}* \text { pipe } \\
\text { inner } \\
\text { wall area }\end{array}$ & $31,557,600$ \\
\hline$(\mathrm{Ci} /$ year $)$ & $\mathrm{cc} \mathrm{H} 2 @ \mathrm{STP} / \mathrm{s} / \mathrm{cm}^{\wedge} 2 * \mathrm{Ci} / \mathrm{cc} \mathrm{H} 2 @ \mathrm{STP}$ & $\mathrm{cm}^{\wedge} 2$ & $\mathrm{~s} /$ year
\end{tabular}

Figure 1. Calculation of Parameters for $1 / 2$ " Schedule 40S Stainless Steel Pipe 
Tritium Remaining in Metallic Waste, CIG Segment 6

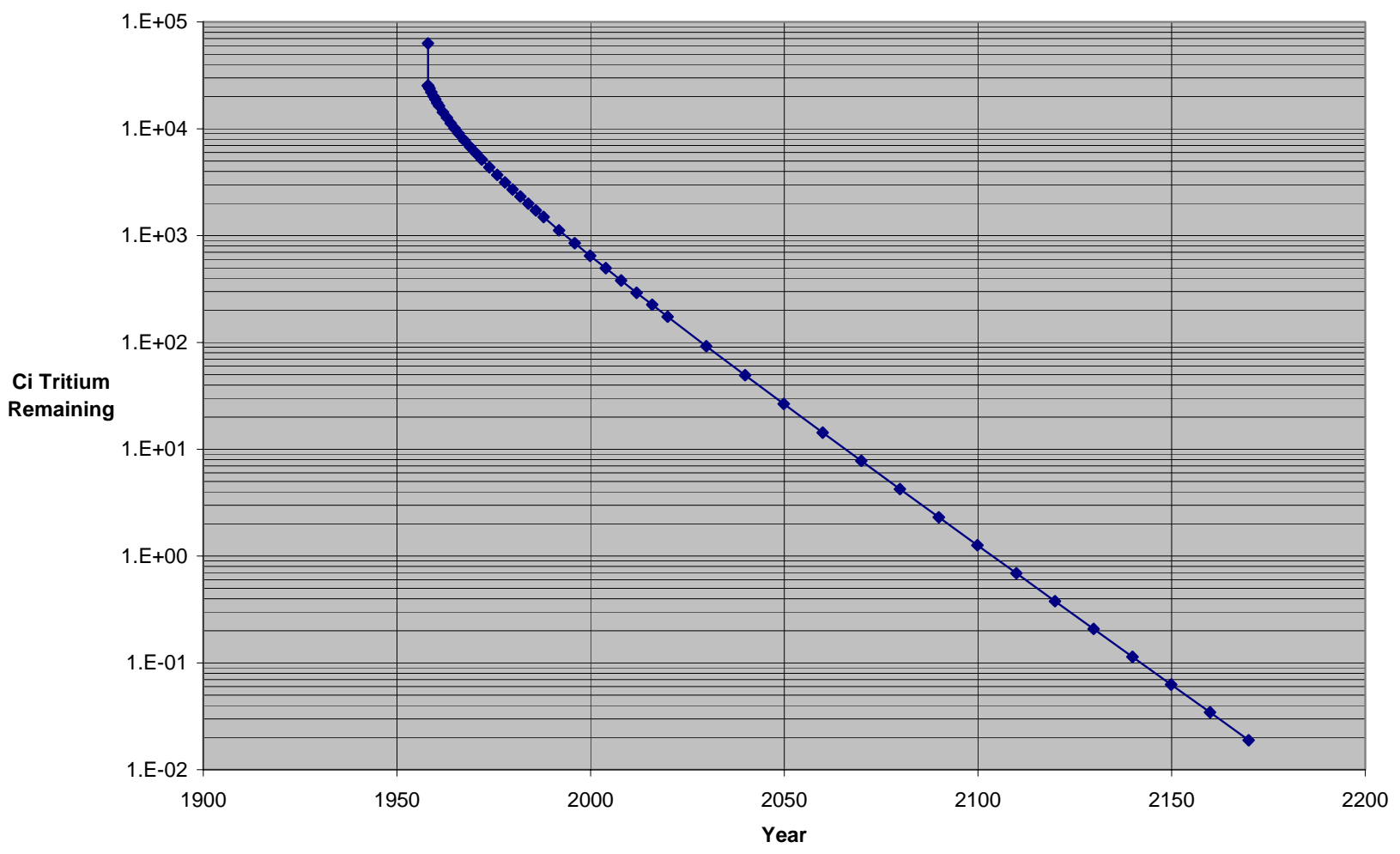

Figure 2. Tritium remaining in CIG Segment 6 metallic waste as a function of year. 
Tritium Source from Waste, CIG Segment 6

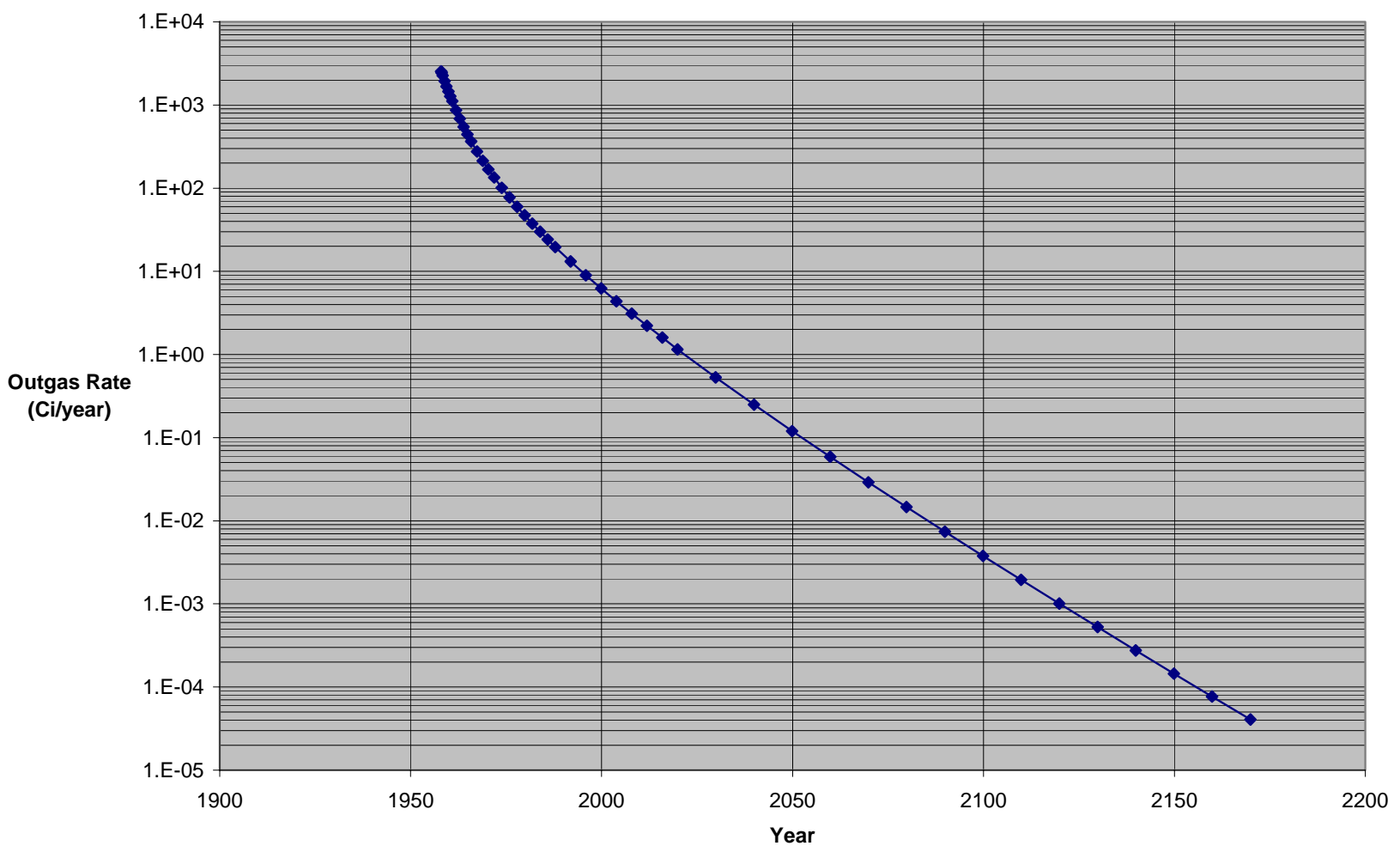

Figure 3. Tritium outgas rate (Ci/year) from CIG Segment 6 waste as function of year. 